\title{
Exploring with Aborigines: Thomas Mitchell and his Aboriginal guides
}

\author{
D.W. A. Baker
}

Thomas Mitchell first arrived in Australia in 1827 as Deputy Surveyor General. He was skilful and experienced having served as a military surveyor in Wellington's army in Portugal and Spain and having spent five years after the war making surveys and plans of the main battlefields on which the British army had fought. He had also published in London a book entitled Outlines of a System of Surveying for Geographical and Military Purposes. So Mitchell combined practical experience with a theoretical understanding of the process of surveying. He was, perhaps, uniquely well equipped to begin the first scientific survey of a British colony.

His four predecessors in the office of Surveyor General had measured land grants, set out some Sydney streets and charted segments of the coastline but had done nothing to produce a general map of the colony by which alone the many land grants could be reconciled one with another.

A general map entailed covering the colony with a series of triangles calculated precisely by the use of a theodolite. None of the earlier surveyors had even attempted this task. When Mitchell arrived in Sydney there was not a theodolite in the colony fit for use but he managed to repair two damaged ones and then began the work of triangulation. ${ }^{1}$

By 1827, Mitchell's immediate predecessor, John Oxley, was dying so Mitchell at once became de facto Surveyor General and lost little time in triangulating the country southwards from Sydney as far as Lake George where he set out as accurately as he could a base line from which to calculate the distances between his trig points.

It was on this southerly surveying trip, begun in May 1828, that Mitchell first got to know some Aborigines and began his association with them as guides, an association which was developed and extended on his four journeys of exploration. ${ }^{2}$

These guides can be divided into four main groups which may be called hired help; passers on; camp followers; and, professionals.

1. Mitchell to Hay, 3 March 1828. Sir George Murray Papers, National Library of Scotland, Adv. MSS. 46.8.7f.8.

2. This surveying trip is described in.Mitchell, T. L., Field, Note and Sketch Book 1828-30, Mitchell Library, C42. 


\section{Hired help}

The guides referred to as hired help have certain common characteristics.

Mitchell found them and used them on the fluctuating margin of settlement, not in the far interior, nor around Sydney or some other town like Bathurst, but very probably on some squatter's run. They all had at least a smattering of English; some of them seem to have been quite fluent. With one or two exceptions, they all had a name which Mitchell recorded. Sometimes it was an Aboriginal name, sometimes a European name. If European, the name might have been given in a satirical or mocking fashion, eg ' $\mathrm{Mr}$ Brown'. Now and then the name was a combination of Aboriginal and European names. An example is 'Billy of Kerraway'.

A fourth characteristic is that they all seem to have had a degree of independence. They were not subject to Mitchell's orders but agreed to do a certain job for a set price. The job might be to assist with so many days' travel or to assist the survey team in reaching a certain destination. The price might be a tomahawk or a blanket or some similar material reward. The going rate, Mitchell discovered, was food and a blanket for ten days' work; such an agreement was usually reached by holding up the fingers of both hands. ${ }^{3}$ The hired help now and then showed their independence by simply walking off the job if it became too onerous or obviously not worth the agreed price. No doubt, from time to time, there must have been misunderstandings about the terms of the verbal contract.

Finally, the hired help, having had some experience of white fellows for most, perhaps for all, of their lives, had a dislike and a fear for what they often termed the 'myall blacks', ${ }^{4}$ those who had had no contact with Europeans. This fear, one might say, this terror of the myall blacks limited the usefulness of the hired help. They would never take Mitchell beyond the country they knew well. They would never venture into the unknown. This strong aversion of the hired help towards the myall blacks seems to be a striking example of the absence of any feeling of there being an Aboriginal community in contrast to the British community.

\section{Particular examples of hired help}

One evening on the southern survey, Mitchell visited several Aboriginal families between Mittagong and Bowral and wanted one of the men to accompany his surveying party as a guide and interpreter but they were strangers to the land further south and frightened of the Aborigines living there. When Mitchell assured them that his party was well armed and that a guide would have nothing to fear, one of the Aborigines said, 'Ah, shoot de Buggers', but none would accompany him. ${ }^{5}$

When Mitchell reached Towrang, half way between Goulburn and Marulan, he enjoyed the companionship of a highly intelligent Aborigine called Primbrubna who agreed to travel with him for a while. In the evenings Primbrubna sang for his own pleasure and the entertainment of the white men. He began with a good performance of an English song, continuing with Aboriginal ones. Mitchell was very impressed with a

3. Ibid., Mitchell's footnote to 7 July 1828. Cf., 10 July 1828.

4. See 'myall' in Ramson 1988, p. 415.

5. Mitchell, T. L., Field, Note and Sketch Book 1828-30, Mitchell Library, C42, 31 May 1828. 
poetical kangaroo song. One verse described the weapons used in the hunt, another recounted an unsuccessful chase, a third was inspired by the night, the fourth celebrated the following daybreak, the next was about the chase renewed and, finally, there was the death of the kangaroo. Mitchell so admired this song that he persuaded Primbrubna to repeat the words slowly and, having written them down, he repeated them to the guide. The flatterer was then flattered because Primbrubna told Mitchell: 'Not stupid fellow you, like other white fellows'. Mitchell then discovered, by looking at the stars with Primbrubna, that Aboriginal astronomy was full of figures of men and animals, the moon having once been a black cockatoo, and so on.

The next morning, Mitchell was shown some marks on trees made with tomahawks a year earlier by Aborigines from Lake George which Primbrubna thought hostile. Soon after, to Mitchell's disappointment, Primbrubna left the surveyors to return to his own people. 6

A little later, Mitchell found another Aborigine to act as a guide. He was called Billy of Kerraway and he, Mitchell and Mitchell's convict servant, called Bates, spent several days and nights surveying and sleeping in the deep and beautiful gorge of the Wollondilly. Billy and Bates looked after Mitchell's comfort very well. The bush bed on which he slept soundly was, he reflected later, the spontaneous handiwork of a robber and a savage.

Billy, and other Aboriginal guides, Mitchell soon discovered, were enormously useful to the surveyors, especially at night when the Europeans often got confused and lost. The Aborigines, on the other hand, had what seemed to be an instinctive knowledge of the ground and a recollection, or wea as they termed it, as true as a compass, of the direction to any spot to which they chose to go.

The amazing accuracy of Billy of Kerraway's wea was demonstrated when the surveyors were camped at the head of the Wollondilly. One morning Mitchell, two other surveyors and Billy left the camp to visit a mountain about six miles $(9.65 \mathrm{~km})$ away through broken and rough bush which could be crossed only on foot. The party climbed the mountain and Mitchell sketched the surrounding country and took angles with his theodolite, being determined to finish before dark to not have to come back to this mountain a second time.

About an hour before sunset, Mitchell finished his work, descended to the spot where his men had made a fire, had a pot of tea and then the four of them started the six mile journey back to the camp. Billy, of course, was the guide and they all strode along, up one hill down the next, crossing ravines, pushing through thick scrub, scrambling across rocky places very contentedly for an hour or so after dark. But presently, Mitchell became impatient and said to one of his men, 'I wonder if this black rascal is taking us the way we came. We ought to be near the tents by this time; by God, I'll trust no man in future, but take the lead myself.'

And then, speaking to Billy, he said, 'Here, come back. Are you taking us to the tents, and have we to go up that damn black mountain?' Billy replied, 'Me make a light directly, me sit down tents directly. This way Massa.' And off he trotted taking the party

6. Ibid., 16-17 June 1828 .

7. Ibid, 3 July 1828. 
up the mountain which Mitchell doubted they had passed before. Up they went puffing and blowing, muttering oaths and damning Billy for going so fast.

At last Mitchell again lost his temper, stopped the party and angrily asked Billy where the tents were. 'Me find him directly,' said Billy and pointed ahead. Mitchell did not know where he was and said to Billy, 'Damn you, are we to cross that infernal mountain too?' 'Bale [no] Massa, me find him directly.' And after another hundred yards or so, the white men found themselves, to their astonishment, outrage and bitter disappointment, at the fire where nearly three hours before they had drunk their pot of tea.

Mitchell was about to explode but saw Billy jumping up and down, capering with delight and shouting, 'Me got him, me got him!' 'Got what?' demanded Mitchell. 'Budgerry pipe, ol murray budgerry pipe', showing a little black pipe about three inches long, for which he had brought Mitchell and his men all the way back by a different route. 'Now', said Billy, 'me make Massa and you (go ) tent directly.' 8

So Mitchell had some quite considerable (if not always happy) experience of Aboriginal guides before he began his four journeys of exploration.

His first journey, in 1831, was northwards from Sydney to the Queensland border at Mungindi. Near Scone he tried to secure an Aboriginal guide but discovered that virtually all the Aborigines had been extirpated from the Hunter valley. Further north, near Murrurundi, an Aborigine from the Liverpool plains came into the camp and Mitchell recruited him as a guide by the present of a pipe. This unnamed man took the expedition to a station near Quirindi. ${ }^{9}$

Here Mitchell hired Jemmy, who, for the price of a tomahawk, agreed to conduct the expedition to the last northern station, a few miles beyond Tamworth. He was helpful to Mitchell's men showing them how cool, clear water could be obtained from a muddy pool by digging a hole in sand nearby. ${ }^{10}$

At this station, the overseer obtained for Mitchell another Aborigine called $\mathrm{Mr}$ Brown who agreed to join the party on condition he was given a tomahawk and blankets for himself and his wife. He was also fed and quickly became addicted to eating flour. Mitchell was most unwilling to waste flour and rationed his men to a pound a day. Mr Brown was eating two and a half pounds but was allowed to eat his fill, so highly did Mitchell value his services.

After a week travelling further north, Mr Brown saw evident signs of myall Aborigines, who had no contact with the white man, and was so terrified that he suddenly ran away to the south, without even asking for his tomahawk and blankets. For the rest of this expedition Mitchell travelled without the assistance of a hired or formal guide. He was, though, helped from time to time by Aborigines who 'passed him on' through their territory to that of their neighbours. ${ }^{11}$

8. W. R. Govett, 'Scrapiana or Note Book', Mitchell Library, B187, No pagination.

9. Mitchell 1839, vol. 1, p. 25.

10. Ibid., pp. 29-33.

11. Ibid., pp. 34-50. 
The final example of the hired help is Bultje, a man for whom Mitchell had some affection and a great deal of admiration. Mitchell first met him on his second journey in 1835 on the western slopes of New South Wales not far from Peak Hill and found him very helpful in finding good water and grass. He met him again at the same place ten years later when he was beginning his fourth journey. On this occasion Bultje was just as obliging and guided Mitchell for four days to reach the Bogan River. For this he was rewarded with a tomahawk, a pipe and two figs (about $60 \mathrm{~g}$ ) of tobacco. Before they parted, Mitchell sketched his singularly Socratic looking face and reflected that he must have also possessed the philosopher's wisdom to have survived where he was, placed between ignorant and often brutal stockmen and shepherds on the one hand, and myall Aborigines on the other.

Mitchell thought that the myall Aborigines would naturally regard those who accommodated themselves to the white men in the same way as he would regard a soldier who deserted to the enemy - that is, as deserving death. Mitchell was also impressed by the fact that Bultje had been living in the same valley for ten years. If this did not give him a valid claim to the soil, it proved, at least, that he had a strong attachment to it and a settled disposition. He thought, too, that Bultje must have had great difficulty in stopping the myall Aborigines from stealing his women and in escaping the anger of the white men when enraged by the depredations of savage Aborigines. He thought it was like running with the hares and hunting with the hounds. ${ }^{12}$

\section{Passers on}

The process of passing on was by no means confined to Australian Aborigines. It was very common in many parts of the world where European explorers first made contact with indigenous inhabitants. It was a process by which people, confronted by strange, possibly threatening or dangerous pale faced intruders, tried to assist them through their territory with as little fuss and damage as possible. Such passers on, with one or two exceptions, knew no English. The passing on had to be conducted by some sort of pantomime or practical assistance.

Passers on probably had some degree of apprehension, some unease or even dread of the trouble which these strangers might bring with them. They were perhaps timid but not so much as to make them run away-though many Aborigines did just that. They had some aversion to the white man but not an implacable hostility such as Mitchell sometimes encountered, notably from what he termed the Spitting Tribe on the Darling near Wilcannia. ${ }^{13}$ Passers on did not want to fight the white intruders but rather to get them through their territory with a minimum of trouble.

Mitchell's first expedition came to an end when a support party bringing up supplies was attacked, two convict servants killed and the supplies plundered. Six days after learning of this disaster, Mitchell was leading his men in their retreat southwards through wooded country that was full of holes and very hard going. The party soon learned they were being closely followed by many Aborigines. One of the convicts dropped behind, fell in with them and found a large iron tomahawk being brandished over his head. He made his escape but was obviously at the Aborigines' mercy.

12. Mitchell 1848, pp. 13-18.

13. Mitchell 1839, vol. 1, pp. 245-8. 
Meanwhile, the main body of the Aborigines, numbering a hundred or more (there were 18 whites) allowed themselves to be seen walking parallel to the route of the slowly moving bullock wagons, in lines of twos and threes as though escorting the foreigners out of their territory. Had they attacked they would surely have killed many, if not all, of the white intruders. The reason for this escort duty, almost military in character, was probably the fear that the white men might seek revenge for the killing of the two convicts; the escorters were simply very anxious to see the whites off their patch. ${ }^{14}$

Some days later, after Mitchell had buried the bodies of the two men killed, he was near Narrabri and about 30 miles $(48 \mathrm{~km}$ ) from the scene of the tragedy. He was leading his party southwards along the wheel tracks his wagons had made on their journey north and he came across a number of spears laid at right angles across the tracks. He dismounted and, approaching a group of Aborigines standing there, he picked up one of the spears and tried to explain that the wagon wheels passing over them would break them. Still the Aborigines would not remove them.

They then called loudly to their women who were at some distance under a tree and plainly invited the explorers to visit them. This invitation being refused, they then called the women over, divested of their cloaks and bags and made them stand before the white men. Each Aborigine seemed to have two women: one plump or fat, the other thinner and much younger. Each man stood before his women, bowing to one and then the other and giving a wave of the hand which Mitchell thought as gracefully intelligible as the gestures of French dancing master. The women showed no indication of fear, aversion or surprise. They seemed, rather, perfectly willing to supply the hospitality kindly offered by their men. The climax came when an especially attractive young girl was placed face to face with the expedition's second in command, George Boyle White. Mitchell abruptly ended the pantomime. He threw the spears off the track and ordered the bullock drivers to proceed. The Aborigines just disappeared.

Very soon, though, the track got soft so that the wagons seemed likely to be bogged. Even the horses began to sink through the surface crust. Earlier, the Aborigines had pointed down the track and then put their hands on their chests as if to indicate depth. They had then pointed to the east as if to show there was a better route there. And so it turned out. The Aborigines had successfully passed on the explorers without having to supply sexual favours. ${ }^{15}$

On his second expedition in 1835 Mitchell travelled down the Bogan to Bourke, then down the Darling to Menindee and then home by his outward track. The journey down the Bogan was assisted by a great deal of passing on. An early case was unusual in that the main guide knew a little English (in fact, very little) and had a name, Tackijally, which Mitchell recorded. On the first day they met, Tackijally took Mitchell down the dry Bogan to some ponds of water where they stopped for nearly an hour while Tackijally vainly cooeed into the surrounding bush. At last a large and impressive man emerged whom Mitchell believed to be an important chief. Tackijally paid him much deference and steadfastly refused to tell Mitchell his name but the white men dubbed him the king. He did not appear to have seen a white man before.

14. Ibid., pp. 120-1.

15. Ibid., pp. 132-5. 
Tackijally guided the explorers for several days, although Mitchell believed, he did not want to but had been ordered to do so by the king. His services were of enormous value for the river was dry except for scattered water holes and Tackijally took the expedition straight from one water hole to the next without them having to follow the many dry bends of the river. Mitchell was amazed at Tackijally's detailed knowledge of the country.

Another advantage was that the party was perfectly safe from the danger of sudden collision with other Aborigines. Tackijally and other guides were always very cautious in approaching water holes, cooeeing loudly from a great distance.

Tackijally guided Mitchell for a week while the king and others of his men travelled parallel with the explorers, sometimes in their company, sometimes unseen at a distance but always, one may be sure, keeping the white men under observation.

Near Nyngan the king and his compatriots had evidently come to the boundary of their territory. The great chieftain pointed out to Mitchell some distant figures seated under a tree and took him forward to introduce him to what Mitchell thought was the Bungan tribe. He then returned with Tackijally and his other men back to his own country. ${ }^{16}$ It was a classical case of passing on.

\section{Camp followers}

Camp followers were a diverse collection of Aborigines who seem to have little in common other than that they attached themselves to Mitchell's party and made themselves useful in one way or another. The main group of camp followers joined Mitchell's third expedition, into Australia Felix, or the western district of Victoria. But one member of the fourth expedition, into northern Queensland, must also be classed as a camp follower.

The first of them was Kitty of Lake Cargelligo. Mitchell had lost no time in recruiting John Piper as his permanent or professional guide for this journey. When they reached Lake Cargelligo, Piper disappeared one night and came back the next morning having somehow or other acquired a wife overnight from Aborigines two hundred miles distant from his home in Bathurst. So Kitty came marching behind Piper into the camp, loaded with a new possum skin cloak and various presents Piper has acquired with her. How Piper had arranged this important matter was a mystery to Mitchell but Kitty became a permanent member of the party.

She was a tall, strong woman with great presence of mind. Her face was strangely disfigured having a blind eye, opaque and white, the result, almost certainly, of smallpox. She made herself useful in various ways, sometimes even advising Mitchell about the route to follow when Piper was otherwise engaged. ${ }^{17}$

The first part of this expedition was down the largely dry bed of the Lachlan. One day, a bit south of Hillston, Kitty came back from the head of the expedition to tell Mitchell that there was water ahead and that there were Aborigines beside it. The party approached cautiously but the Aborigines were terrified and, as was very often the case, they fled leaving behind a boy, aged perhaps seven or eight, who was quite blind

16. Ibid., pp. 193-204.

17. Ibid., vol. 2, pp. 37-8, 103-4, 135 . 
(again, probably due to smallpox) and a girl, aged about four, who sat down beside the boy. Presently the girl's mother appeared and she was persuaded by Piper and Kitty to join the expedition. Her name was Turandurey; her daughter was called Ballandella. ${ }^{18}$

Turandurey proved to be an excellent guide. She was a widow and about 30 years of age. She knew the country well and was adept at finding water. She could converse freely with the Aborigines of the lower part of the Lachlan and also with Piper.

Furthermore, Mitchell discovered, the Aboriginal men in this part of the world could not at once talk to each other. A convention demanded silence and patience for some considerable time while two men sat down a few yards apart waiting until it was proper to converse. This delay irritated Mitchell enormously. However, no such convention inhibited women and Turandurey's usefulness was therefore increased. ${ }^{19}$

When the party reached the Murrumbidgee they saw a group of Aborigines on the other side of the river and Turandurey stood boldly forward and addressed the men opposite her in a very animated and apparently eloquent manner. Mitchell admired her appearance and earnestness of manner and delighted in the confident authority with which she spoke. He thought he was very fortunate to have met with such an interpreter for she succeeded in persuading the Murrumbidgee Aborigines to swim the river and talk to him about the country. From these discussions, Mitchell was confirmed in his belief that the Murrumbidgee eventually ran into the Murray and that this larger river was joined at a greater distance by another river from the north - the Darling. ${ }^{20}$

At about the time when Turandurey was enlisted, two other young Aborigines attached themselves to Mitchell's party. They were both called Tommy and Mitchell's men, to distinguish between them, gave them chronometrical surnames: Tommy CameFirst and Tommy Came-Last. Mitchell was always aware of the need to conserve his food supplies and did not want to support unnecessary camp followers and ordered that Tommy Came-First be told to leave the party. But Tommy refused. He said he would follow the party despite the 'Majy's' orders as he could always find possums in the trees. When Mitchell was told this, he was pleased by Tommy's independence and allowed him and Tommy Came-Last to remain with the expedition. ${ }^{21}$.

Near the junction of the Murrumbidgee with the Murray an unfortunate accident occurred which made it impossible for Turandurey and Ballandella to leave the expedition, even had they wanted to. Ballandella fell from the cart in which she was riding and a wheel ran over and broke her thigh. Mitchell had a medical attendant who at once set the fracture in splints and the girl eventually recovered but for a long time she was immobilised and her mother obliged to nurse her. ${ }^{22}$

Towards the end of this third expedition, Turandurey, though as affectionate as any mother could be, decided to entrust her daughter to Mitchell's care. She probably despaired of ever being able to train her daughter in her traditional ways and realised,

18. Ibid., pp. $60,62-4$.

19. Ibid., pp. 67-8.

20. Ibid., pp. 75-7.

21. Ibid., pp. 67.

22. Ibid., pp. $86-7$. 
according to Mitchell's account of her feelings, that women were much better treated by Europeans than by Aborigines. ${ }^{23}$

After the journey was over, Turandurey got a new husband, King Joey from the Lachlan, and received two blankets as a wedding present from the expedition's stores. Ballandella was adopted into Mitchell's family and sent to school. Later she married and her descendants have been traced into this century. ${ }^{24}$

The last Camp Follower was a ten-year-old boy called Dicky who joined the fourth expedition on the northernmost cattle station on the Bogan. Although so young, he had an excellent local knowledge of the river and its waterholes which was very useful to the explorers. It was a very hot summer with temperatures up to $43^{\circ}$ and water hard to find. ${ }^{25}$

A few weeks later, the party was travelling north along the Macquarie River through reeds and tall grasses. An incompetent bullock driver lost two of his animals and was quite unable to find them. He appealed to Dicky to go back with him and recover the lost beasts. Mitchell realised that it must have seemed very odd to the Aborigines that the white man who brought such large and easily traceable animals as oxen into their country should be unable to find them without the assistance of a mere child of their own race. ${ }^{26}$

Dicky stayed with Mitchell for the whole of the expedition and became a willing servant to Yuranigh, Mitchell's professional guide on this expedition. Yuranigh's affection for the boy seemed to Mitchell to be quite paternal as he instructed him how to behave. After the joumey Mitchell took Dicky into his own home where he became a favourite with Mitchell's other children, five of whom were about Dicky's age or younger. ${ }^{27}$

\section{Professionals}

The two professionals Mitchell employed have already been mentioned: Piper, on the third expedition, and Yuranigh, on the fourth.

Piper came from Bathurst and was originally known to Europeans as 'Piper's Boy' which became abbreviated to Piper. He was a young man in 1836; we might guess that he was 20 or 25 years old. He was old enough to take a wife but not old enough to eat the flesh of an emu. Had he done so, he believed, he would have suffered boils all over his body. Presently though, Piper decided that he was old enough to eat emu. The ceremony that would enable him safely to do so consisted chiefly in being rubbed all over with emu fat by an 'old man'. This task fell to a convict, John Richardson, who was 39. Once anointed by Richardson, Piper had no objection to eating emu. ${ }^{28}$

Piper spoke English reasonably well and agreed to accompany Mitchell wherever he went provided he was clothed, fed and allowed a horse. He proved invaluable. Fre-

23. Ibid., pp. 265-6.

24. Ibid., pp. 335-6, 339-40, 352. Brook 1988, pp. $63-76$.

25. Mitchell 1848, pp. 25-6.

26. Ibid., pp. 64 .

27. Ibid., pp. 415.

28. Mitchell 1839, vol. 2, pp. 3-4, 29, 346 . 
quently he was able to persuade other Aborigines met with on the expedition's long march to pass the party through their territory. He was also often able to elicit geographical information from local inhabitants such as the course of rivers, the names of topographical features and so on.

Piper, along with the other Aborigines, made the 'white fellows' look rather stupid in the bush. They could read the tracks on the ground, climb trees or dive into the water far better than the British. In tracing lost cattle, speaking to 'wild black fellows', in hunting or diving, Piper, Mitchell acknowledged, was the most accomplished man in the camp. ${ }^{29}$

He was also the tallest and thought of himself as second in authority only to the 'Majy' himself. When Granville Stapylton, the real second in command, joined the expedition three weeks after it had begun, Piper went to Mitchell's tent and declared that 'That fellow has two coats', implying that Mitchell should give one of them to him. Piper, who must have experienced the transportation system at Bathurst and well knew the distinction between bond and free, despised the convicts and would act only on Mitchell's orders. He was, in short, a highly skilled and independent young man. ${ }^{30}$

If Piper had a weakness it was probably, like Mitchell's, a shortness of temper. He could quickly become frustrated and angry with people if they did not do what he wanted. Near Hamilton in Victoria for example, Piper found two Aborigines and tried to persuade them to come into the camp and talk to Mitchell. His knowledge of the languages spoken so far south was probably very slight and he made little progress. Finally, he was so enraged at what he thought was the unreasonable timidity of one of these men, that he hurled his tomahawk at him as he sidled off into the bush. ${ }^{31}$

Back in Sydney, at the end of the journey, Piper seemed to relish more than anyone else the triumph of the successfully completed expedition. Mitchell clothed him in his own red coat and gave him a splendid cocked hat and feather which had belonged to Governor Darling. Piper's portrait thus arrayed soon appeared in the Sydney print shops, an enterprising artist having drawn his likeness very accurately. But he soon tired of life in Sydney and became impatient to return to his own country near Bathurst. Mitchell carefully observed all the conditions of their agreement and decorated him

with a brass plate on which he was styled, not as usual 'King', for, Piper said, there were 'too many Kings already', but as 'Conqueror of the Interior' - a far more splendid title. $^{32}$

Some years later, in 1843, Piper told a Bathurst surveyor that he would be willing to accompany Mitchell on another exploring expedition. When Mitchell heard this he was delighted because he was then planning his fourth expedition into northern Queensland to discover a route to the gulf of Carpentaria and he thought Piper's services would be invaluable to the success of the journey. ${ }^{33}$

29. Ibid., p. 162.

30. Ibid.

31. Ibid., p. 256.

32. Ibid., pp. 338-9.

33. Mitchell to Davidson, 13 November 1843. Letters of T. L. Mitchell to W. R. Davidson, Mitchell Library, A296. 
Accordingly, when Mitchell set out for the north at the end of 1845 he took Piper with him and provided for him a horse and saddle, a double-barrelled shot gun, clothing, rations, blankets and so on. He also recruited another Bathurst Aborigine named Yuranigh. Soon the young boy, Dicky, joined up too. ${ }^{34}$

By the end of January 1846, when the party was camped for a few days near Nyngan, Mitchell was informed that Piper had heard that women were available close at hand and that he was planning to desert and take Yuranigh and Dicky with him in search of female companions. Mitchell felt betrayed by Piper and threatened by the loss of the other two Aborigines. He had Piper arrested and sent back under police guard to Bathurst where he could no longer suborn Yuranigh or Dicky. ${ }^{35}$

So Yuranigh replaced Piper as the professional for the fourth expedition. It was a change, Mitchell thought, for the better. He had nothing but praise for Yuranigh who became, he said, his 'guide, companion, councillor and friend' ${ }^{36}$

Younger than Piper (for he would not eat emu), Yuranigh was small and slender in person but possessed of the most determined courage and resolution. His intelligence and judgment were so necessary to Mitchell that he always kept him at his elbow when travelling. He accepted his advice above that of any white man in his party. ${ }^{37}$

Yuranigh fully understood the character of all the white men on the expedition and could distinguish between the reliable convicts and the handful of recalcitrants who were not to be trusted. He was particularly clean in his person, washed frequently and always kept his glossy shining black hair well combed. Consequently he always had a clean and respectable appearance. ${ }^{38}$

Yuranigh seems to have been more skilful than Piper in securing local Aboriginal guides. He was more patient and less impetuous. Soon after reaching the Balonne, for example, the party came across a man and a woman fishing with nets. Yuranigh went up to them and returned with the man who left the woman behind to look after the nets. The man very willingly took the party further north and Mitchell was very impressed that Yuranigh had the skill to persiade him so easily and quickly though each scarcely understood a word the other spoke. ${ }^{39}$

Yuranigh was also a close observer of the country they passed through. He could draw Mitchell's attention to features of the landscape he might otherwise have missed. One frequent problem Mitchell faced when travelling along a river, especially if it were dry (as most outback rivers usually are), was to decide which of the two channels they came across was the main one. Yuranigh was seldom wrong in his judgment of such matters. ${ }^{40}$

He could also teach Mitchell about flora and fauna, showing him, for example, small differences between different species of fresh water mussels that he had failed to

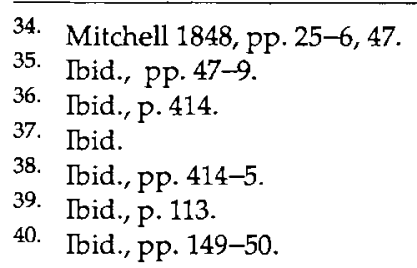


distinguish. Sometimes such advice was put very vividly. The crows of central Queensland, Yuranigh said, 'talked another language' from those near Sydney. ${ }^{41}$

When the journey was over, Mitchell provided hospitality for Yuranigh and Dicky in his own home and secured from the Governor a small gratuity for his 'guide, companion, councillor and friend'. Yuranigh had been to Sydney before and took a lot of pleasure in showing Dicky, who had never before seen a house, all the sights including a trip to the theatre. ${ }^{42}$

The holiday over, Yuranigh was engaged as a stockman, for wages and under a regular agreement, by a squatter with a cattle station in the northern part of the colony. He later returned to Molong and died there in 1850. Two years later, Mitchell arranged for his grave to be fenced and a headstone erected. This memorial, replaced in 1900, reads:

\author{
To Native Courage \\ Honesty and Fidelity \\ Yuranigh \\ who accompanied the \\ Expedition of Discovery \\ Into Tropical Australia in 1846 \\ lies buried here \\ According to the Rites \\ Of his countrymen \\ and this spot was \\ dedicated and enclosed \\ by the Governor General's Authority \\ in $1852 .{ }^{43}$
}

Two questions should be asked about these Aboriginal guides: one, were they essential to the success of Mitchell's expeditions? And, secondly, were the guides acting, as it were, as nineteenth century Quislings, betraying their country to the white invaders and acting as collaborators in the destruction of their own society?

One cannot answer this first question with certainty but it is probable that Mitchell and his parties could have carried out extensive journeys in the interior without Aboriginal help because, in fact, they did so. On his first and second journeys, Mitchell had no professional help and at times travelled extensive distances without help from passers on, often without any contact with any Aborigines at all.

From the 20th of December 1831, when Mr Brown deserted the party, not far from Boggabri, until the end of January 1832, when Mitchell reached the Barwon near Mungindi, he received no Aboriginal guidance whatsoever. It was a period of six or seven weeks during which he covered 400 or 500 miles $(643-804 \mathrm{~km}){ }^{44}$

Similarly on the second expedition, 12 days elapsed between the time Tackijally finished passing on the explorers till Mitchell again got some Aboriginal assistance near

41. Ibid., pp. 225, 252.

42. Ibid., p. 415.

43. Mulvaney 1989, p. 84 .

44. Mitchell 1839, vol.1, pp. 50-95. 
the junction of the Bogan and the Darling. The travellers had covered about 120 miles $(192 \mathrm{~km})$ on their own resources. ${ }^{45}$

So it is clear that Mitchell and his men were capable of travelling extensive distances through the bush without Aboriginal guides.

However it is also true that the expeditions travelled more quickly, and therefore further, before their food supplies were exhausted when they enjoyed the help of Aboriginal guides. Guides made the journeys faster in two ways. Firstly, in helping Mitchell find the best route to take to his chosen destination. This, after all, is what guides are for. And, secondly, in tracking straying stock.

On all his journeys, Mitchell relied on bullocks and there was always the problem of stopping them straying at night time. They could not be too closely confined, for example by leaving them yoked to their wagons, because they had to graze and it often happened that, in search of grass, they wandered off out of sight and the expedition had to wait in the morning till all were found. Sometimes Mitchell felt as though he were a sailor at sea unable to move because utterly becalmed. It made him irritated and impatient and the Aboriginal guides, even young Dicky, were excellent trackers. ${ }^{46}$

We should also recognise, when asking whether guides were essential to the success of the expeditions, that guides made the expeditions safer. Whether hired help, passers on, camp followers or professionals, guides greatly reduced the risk of conflict with myall Aborigines. Guides were usually quicker than white men in apprehending danger. Passers on had, as one of their main aims, the avoidance of conflict. The mere presence of Aborigines in Mitchell's camp or entourage must have done something to alleviate myall Blacks' fears and suspicions. Piper and Yuranigh, as full time professionals, became skilled at warning of danger, at estimating risks and at placating hostility.

For example, at the end of March 1846, Mitchell was travelling up the Narran, a bit north of the Queensland border. He was assisted by two local guides Yuranigh had recruited. After the main party had made camp, Mitchell reconnoitred further on with Aboriginal guides. They approached some bush and Dicky, by an anguished scream, first drew Mitchell's attention to a black line of battle drawn up within the trees. Yuranigh halted but one of the two local guides went on and talked with the armed warriors. The other local guide urged Mitchell to go forward but Yuranigh would not advance another step though much pressed to do so. He declared that 'those fellows were murry coola', or very angry. So Mitchell prudently retired. ${ }^{47}$

In these several ways, then, guides certainly reduced the dangers confronting Mitchell, very real dangers as shown by the number of surveyors killed around this time.

Finally, were these guides traitors, betraying their country to the white invaders and acting as collaborators in the destruction of their own society?

Mitchell was frequently aware of what was at least a certain irony in the way Aboriginal guides were assisting the spread of European cattle that all too often endangered

45. Ibid., pp. 204-212.

46. Ibid., pp. 28; vol. 2, pp. 217-8. Mitchell 1848, p. 73.

47. Ibid., pp. 109-10. 
or destroyed the Aborigines' water holes. In southern Queensland he once noted that the local Aborigines were doing everything in their power to assist him while his wheel tracks would probably bring the white man's cattle into their country and take it over. ${ }^{48}$

But putting the question in terms of traitors betraying their country is perhaps a mistake because it assumes that Aborigines had notions of broad Aboriginal loyalty and betrayal they probably lacked or, possibly, in some places, were just beginning to develop.

There seems to have been at that time little sense of an Aboriginal community. And without a sense of community the idea of loyalty to it is pretty well devoid of meaning. Aborigines in Australia had lived for many millennia with so little contact with the rest of the world that there could have been little feeling that they constituted a nation or a people; little feeling of us against them.

There is no reason to doubt that Aborigines had feelings of loyalty to family, tribe or clan but in the first half of the nineteenth century there could have been little feeling of an Aboriginal community. There was, rather, a multiplicity of Aboriginal communities.

Thus it became possible for colonial governments to recruit and use native police quite extensively from 1837 to 1900 in areas where the police were 'foreigners'. Similarly, the fear and antipathy shown by the hired help of the squatting districts towards the myall Aborigines indicates the lack of an Aboriginal community. Their plea to Mitchell was simply to 'shoot de buggers'.

Only once in all of Mitchell's journals was there a hint, but no more than a hint, of Aboriginal solidarity against the white men. Near Swan Hill, Mitchell left Piper and the two Tommies to try to discover from the local Aborigines the name of Lake Boga. There were a dozen men armed with spears and boomerangs. When Piper asked the name of the lake, he later reported to Mitchell, he was told very angrily 'I won't tell you'. They then said that there was 'too much ask' about him and 'they blamed him for bringing the whitefellows there'. An old man called on the rest to kill him; two spears were immediately thrown which Piper parried with his carbine. He shot the foremost assailant in the jaw. The rest fled. The wounded man fell; Piper reloaded and killed him with a shot through the body. In Mitchell's experience, it was a unique plea for Aboriginal solidarity which clearly did not exist. ${ }^{49}$

These Aborigines at Lake Boga were no doubt myalls in Piper's eyes but they must have had some knowledge of the white invaders. They were only about 60 miles $(96.56 \mathrm{~km})$ from the junction of the Murrumbidgee with the Murray and must surely have heard about, if they did not actually see, Sturt's big canoe as it sailed the two rivers six years earlier; the memory of it was still vivid in the eyes of men living a little lower down the Murray. ${ }^{50}$ Indeed it is quite likely that they had heard of the massacre on the Darling the previous year for the Darling Aborigines had danced a corroboree near the junction of the two rivers only about six weeks earlier. ${ }^{51}$ They were probably aware,

\footnotetext{
48. Ibid., pp. 83, 90. Cf. pp. 14, 69-70, 306 .

49. Mitchell1839, vol. 2, pp. 143-4.

50. Ibid., p. 120.

51. Ibid., pp. 130-1.
} 
therefore, that the white fellows were dangerous but they could not have known, as did the professionals and the hired help from the squatting districts, just how dangerous they were. They could not have known, nor probably could they comprehend, the enormity of the white man's expropriation of the land and the killing or driving off its original inhabitants and guardians. The very multiplicity of Aboriginal communities must have made it more difficult or impossible for them to envisage an overarching white community that would all too often destroy them.

So it seems too simple to accuse Mitchell's guides of treacherously betraying their country. Rather they were making, in their different ways, personal adjustments to accommodate themselves to the coming of the white man; seeking to fit into a new society they could neither evade nor understand. It was a predicament for which there was no solution.

Don Baker is a Visiting Fellow in the Department of History of the Faculties at the Australian National University.

\section{References}

Brook, J. 1988, 'The widow and child', Aboriginal History, vol. 12, pp. 63-76.

Mitchell, T. L. 1839, Three Expeditions into the Interior of Eastern Australia, 2 vols., London.

1848, Journal of an Expedition into the Interior of Tropical Australia, London.

Mulvaney, D. J. 1989, Encounters in Place, Outsiders and Aboriginal Australians 1606-1985, St. Lucia, Queensland.

Ramson, W. S. ed. 1988, Australian National Dictionary, Melbourne. 